\title{
PENERAPAN KURIKULUM ISMUBA TERHADAP PEMBENTUKAN KARAKTER ISLAMI SISWA SMP MUHAMMADIYAH BANGUNTAPAN
}

\author{
Astuti Budi Handayani ${ }^{1}$, Hendro Widodo ${ }^{2}$ Waluyo Erry Wahyudi ${ }^{3}$ \\ astutibudihandayani12@gmail.com \\ Universitas Ahmad Dahlan Yogyakarta ${ }^{1,2}$ \\ Universitas Islam Negeri Raden Intan Lampung ${ }^{3}$
}

\begin{abstract}
This study describes the application of the ismuba curriculum for Islamic character formation to students of Banguntapan Muhammadiyah Middle School, where moral degradation occurred in Banguntapan Muhammadiyah Middle School students. The purpose of this study was to analyze the application of the Islamic curriculum in the formation of Islamic character in students of Banguntapan Muhammadiyah Middle School. Whereas, the research method used by the researcher is descriptive qualitative method, which is to reveal various conditions found in the field relating to the implementation of the Islamic curriculum at the Banguntapan Muhammadiyah Middle School. The data source consisted of primary and secondary sources, namely the principal, curriculum developer, Islamic curriculum documents, curriculum documents of the Muhammadiyah Middle School Banguntapan, and documents related to the school curriculum. Based on the results of the study it can be concluded that the application of the Islamic curriculum to shape Islamic character in students of Muhammadiyah Middle School Banguntapan has gone according to plan, and became a habit in the Muhammadiyah Middle School Banguntapan, so that little by little the Islamic character of students began to form. However, it is undeniable that there are some shortcomings in its implementation, including not all teachers other than the Ismuba teacher are directly involved in the habituation of Islamic programs.
\end{abstract}

Keywords: moral degradation, iislamic curriculum, character education

\begin{abstract}
Abstrak
Penelitian ini memaparkan tentang penerapan kurikulum ismuba untuk pembentukan karakter islami pada siswa SMP Muhammadiyah Banguntapan, dimana terjadinya degradasi moral pada siswa SMP Muhammadiyah Banguntapan. Tujuan penelitian ini untuk menganalisa penerapan kurikulum ismuba dalam pembentukan karakter islami pada siswa SMP Muhammadiyah Banguntapan. Sedangkan, metode penelitian yang peneliti gunakan adalah metode kualitatif deskriptif, yaitu mengungkapkan berbagai kondisi yang ditemukan di lapangan yang berkaitan dengan pelaksanaan kurikulum ismuba di SMP Muhammadiyah Banguntapan. Sumber data terdiri dari sumber primer dan sekunder, yaitu kepala sekolah, pengembang kurikulum, dokumen kurikulum ismuba, dokumen kurikulum SMP Muhammadiyah Banguntapan, serta dokumen-dokumen yang terkait denga kurikulum sekolah. Berdasarkan hasil penelitian dapat disimpulkan bahwa penerapan kurikulum ismuba untuk membentuk karakter islami pada siswa SMP Muhammadiyah Banguntapan sudah berjalan sesuai dengan rencana, dan menjadi pembiasaan di SMP Muhammadiyah Banguntapan, sehingga sedikit demi sedikit karakter islami pada siswa mulai terbentuk. Akan tetapi memang tidak dipungkiri ada beberapa kekurangan dalam pelaksanaannya, di antaranya belum semua guru selain guru ismuba terlibat langsung dalam pembiasaan program-program ismuba.
\end{abstract}

Kata Kunci: Degradasi moral, kurikulum ismuba, pendidikan karakter. 


\section{PENDAHULUAN}

Degradasi moral atau karakter bangsa Indonesia menjadi salah satu keprihatinan di era disrupsi ini. Hal ini ditandai dengan meningkatnya tindak kekerasan, tawuran antar pelajar, pornografi dan pornoaksi yang semakin merajalela, penyalahgunaan obat terlarang yang sulit terbendungkan, tindak korupsi secara besar-besaran oleh kalangan elit politik, serta krisis kepercayaan yang terjadi pada elit masyarakat (Gumanti et al., 2018; Komarudin, 2017; Ramdhani, 2017). Masalah-masalah tersebut tidak bisa lepas dari peran pendidikan dalam pembentukan karakter bangsa, karena tidak bisa dipungkiri bahwa pendidikan sangat berpengaruh terhadap kualitas moral masyarakat (Hamidah \& Suherman, 2016; Islam, 2017; Rodiawati \& Komarudin, 2018).

Sejalan dengan UU Sikdinas No 20 tahun 2003 tentang sistem pendidikan nasional menyebutkan bahwa pendidikan nasional berfungsi mengembangkan dan membentuk watak serta peradaban bangsa yang bermartabat dalam rangka mencerdaskan kehidupan bangsa, bertujuan untuk berkembangnya potensi peserta didik agar menjadi manusia yang beriman dan bertakwa kepada Tuhan Yang Maha Esa, berakhlak mulia, sehat, berilmu, cakap, kreatif, mandiri, dan menjadi warga Negara yang demokratis serta bertanggungjawab (Hartinah et al., 2019; Lestari, 2018; Wardoyo, 2015).

Terjadinya degradasi moral pada peserta didik saat ini diindikasi karena pembelajaran pendidikan agama dan budi pekerti di sekolah masih hanya sebatas teori tentang apa, mengapa, belum mengarah pada bagaimana teori itu diterapkan dalam kehidupan sehari-hari. Selama ini juga dalam pendidikan di Indonesia lebih menitikberatkan pada pengembangan kognitif saja, sedangkan aspek soft skill atau nonakademik dikesampingkan (Akhwan, 2014; Andriani et al., 2019; Kamandoko \& Suherman, 2017), sehingga belum bisa terwujud tujuan pendidikan nasional.

Selama ini pemerintah telah mencanangkan gerakan pendidikan budaya dan karakter bangsa sebagai wujud untuk mencapai tujuan pendidikan nasional dengan diberlakukannya Kurikulum 2013 (R. D. Utami, 2016; T. N. Utami et al., 2018). Dalam kurikulum 2013 ini diharapkan mampu menanamkan akhlakul karimah dan budi pekerti pada peserta didik untuk memajukan pendidikan nasional dalam menyongsong era disrupsi. Dibandingkan dengan kurikulum sebelumnya, kurikulum 2013 ini 
menitikberatkan pada pendidikan karakter siswa (Fahrudin, 2017; Yanti \& Syazali, 2016). Pendidikan karakter menjadi sebuah keharusan untuk diterapkan dalam pembelajaran di sekolah, karena pendidikan tdak hanya menjadikan peserta didik menjadi cerdas secara kognitif, akan tetapi juga harus memiliki budi pekerti serta kesopanan, sehingga bermakna ketika hidup bermasyarakat (S. Huda et al., 2019; Judiani, 2010; Yunianto et al., 2019).

Pendidikan karakter merupakan upaya untuk membantu perkembangan jiwa anak-anak menuju ke arah peradaban yang manusiawi dan lebih baik. Sebagai contoh, misalnya pembiasaan kepada peserta didik untuk duduk yang baik, rapi dalam berpakaian, tidak teriak-teriak ketika di dalam kelas, hormat terhadap orang yang lebih tua, menyayangi teman, suka menolong teman yang sedang kesusahan, dan lain sebagainya itu merupakan proses pendidikan karakter (Anggoro, Efendi, et al., 2019; Efendi, 2017).

Kurikulum Pendidikan Agama Islam memiliki kedudukan yang sangat penting dalam membentuk karakter seseorang. Kurikulum PAI merupakan suatu perangkat rencana dan pengaturan mengenai tujuan, isi, bahan, serta cara pembelajaran yang digunakan sebagai pedoman penyelenggaraan kegiatan pembelajaran guna mencapai tujuan pendidikan (Damayanti et al., 2019; Farida et al., 2019; Widayanti, 2019). Di sekolah Muhammadiyah kurikulum PAI disebut dengan istilah kurikulum ISMUBA (alIslam, Kemuhammadiyahan dan Bahasa Arab) yang disusun oleh Tim Majelis Pendidikan Dasar dan Menengah Pimpinan Pusat Muhammadiyah. Kurikulum ismuba ini sebagai salah satu upaya untuk meningkatkan mutu pendidikan muhammadiyah dengan memperhatikan perkembangan ilmu pengetahuan dan teknologi serta harapan masyarakat (A. N. Huda, 2018)

Dalam realitas yang lebih sempit misalnya di SMP Muhammadiyah Banguntapan juga mengalami degradasi moral dan karakter. Misalnya masih banyaknya siswa yang berbicara kotor, meninggalkan sholat lima waktu, kebiasaan merokok, dan lain sebagainya. Padahal notabene SMP Muhammadiyah Banguntapan lebih banyak mendapatkan jam pelajaran Pendidikan Agama Islam dibandingkan dengan sekolah negeri. Apakah SMP Muhammadiyah Banguntapan belum menerapkan pendidikan karakter? Berdasarkan wawancara awal peneliti kepada Kepala Sekolah SMP 
Muhammadiyah Banguntapan pada tanggal 16 Mei 2019 menjelaskan bahwa pendidikan karakter telah diterapkan dengan baik melalui pelaksanaan pendidikan agama dalam hal ini adalah kurikulum ismuba, seperti tadarus pagi, sholat dhuha, dhuhur berjamaah, TPA, dan lain sebagainya. Dalam artikel ini akan dipaparkan hasil dari penelitian di SMP Muhammadiyah Banguntapan tentang penerapan kurikulum ismuba dalam pembentukan karakter islami pada siswa SMP Muhammadiyah Banguntapan.

Beberapa penelitian terkait kurikulum berkarakter telah banyak diterapkan, hasil dari penelitian tersebut antara lain guru sebagai ujung tombak dalam implementasi kurikulum dituntut menjadi guru yang mampu meramu kurikulum 2013 secara tepat yaitu proses penilaian dan kompetensi mampu meningkatkan kompetensi siswa yang berkarakter dalam menghadapi tantangan global (Rumapea, 2014), pendidikan karakter perlu dilaksanakan dalam tuntutan kurikulum (Rizqi et al., 2013), dan perlunya karakter siswa dalam membangu kehidupan bangsa melalui dunia pendidikan untuk menghasilkan lulusan yang berkualitas dan berkarakter religius (Nuriyanto, 2014).

Terdapat perbedaan penelitian ini dengan sebelumnya bahwa pada penelitian ini menerapkan kurikulum ismuba dalam membentuk karakter siswa SMP. Sehingga tujuan penelitian ini adalah menganalisa penerapan kurikulum ismuba dalam pembentukan karakter islami pada siswa SMP Muhammadiyah Banguntapan

\section{METODE PENELITIAN}

Penelitian ini merupakan penelitian deskriptif kualitatif, yaitu mengungkapkan berbagai kondisi yang ditemukan di lapangan yang berkaitan dengan pelaksanaan kurikulum ismuba di SMP Muhammadiyah Banguntapan. Dalam penelitian kualitatif, gejala dar suatu objek bersifat holistik (menyeluruh, tidak dapat dipisah-pisahkan), sehingga peneliti kualitatif tidak akan menetapkan penelitiannya hanya berdasarkan variable penelitian, tetapi keseluruhan situasi sosial yang diteliti yang meliputi aspek tempat, pelaku, dan aktitas yang berinteraksi secara sinergis (Sugiono, 2007). Pendekatan yang digunakan dalam penelitian ini adalah pendekatan studi kasus secara konseptual, yaitu suatu penelitian yang diarahkan untuk menghimpun data, mengambil makna, memperoleh pemahaman dari kasus tersebut (Suryawati, 2016). 
Sumber data dalam penelitian ini ada dua macam yaitu sumber data lapangan dan sumber data dokumenter. Adapun sumber data lapangannya adalah Kepala Sekolah SMP Muhammadiyah Banguntapan, pengembang kurikulum. Sedangkan sumber data dokumenternya adalah berupa kurikulum ismuba, kurikulum SMP Muhammadiyah Banguntapan, serta buku-buku penunjang lainnya (Tantowi \& Widodo, 2019). Metode pengumpulan data dalam penelitian ini menggunakan metode observasi, wawancara, serta dokumentasi. Jenis wawancara yang digunakan dalam penelitian ini adalah jenis wawancara terpadu atau terpimpin atau dalam istilah lain kebebasan dalam wawancara dibatasi oleh bahan yang disiapkan. Triangulasi yang digunakan adalah triangulasi metode. Metode ini digunakan untuk mengumpulkan data yang terkait dengan penerapan kurikulum ismuba dalam pembentukan karakter islami pada siswa SMP Muhammadiyah Banguntapan.

\section{HASIL PENELITIAN DAN PEMBAHASAN}

Kurikulum dapat diartikan sebagai sebuah dokumen perencanaan yang berisi tentang tujuan yang akan dicapai, isi, materi dan pengalaman belajar yang harus dilakukan peserta didik, strategi dan cara yang dapat dikembangkan, evaluasi yang dirancangkan untuk mengumpulkan informasi tentang pencapaian tujuan, serta implementasi dari dokumen yang dirancang dalam kehidupan nyata (Akhwan, 2014). Kurikulum memiliki peran yang sangat penting dalam proses pendidikan, walaupun bukan satu-satunya faktor utama. Sehingga kurikulum bisa menjadi penuntun dalam pelaksanaan pendidikan, dalam hal ini adalah penuntun bagi pendidik dan tenaga kependidikan. Oleh karena itu, pendidik dan tenaga kependidikan yang baik adalah yang mampu memahami kurikulum dan dapat menerapkannya dalam proses pembelajaran (Machali, 2014).

Terkait dengan kompetensi masa depan yang diperlukan peserta didik untuk menghadapi era disrupsi adalah kemampuan berkomunikasi, kemampuan berpikir jernh dan kritis, kemampuan mengedepankan moral dalam permasalahan, kemampuan mencoba untuk menghargai dan toleransi terhadap perbedaan orang lain, kemampuan hidup bermasyarakat, memiliki rasa tanggungjawab terhadap lingkungan sekitar, serta memiliki kecerdasan sesuai minat dan bakatnya (Machali, 2014). Akan tetapi dilihat 
dari perspektif masyarakat, pendidikan di Indonesia terlalu menitikberatkan pada aspek kognitif saja dan masih kurang dalam segi pembentukan karakter siswa sesuai denga tujuan pendidikan Indonesia. Hal ini diindikasi dengan makin maraknya perkelahian antar pelajar hanya karena masalah sepele, maraknya penyalahgunaan narkoba, kecurangan dalam ujian, korupsi, dan lain sebagainya. Disinilah peran kurikulum dalam mata pelajaran Pendidikan Agama Islam sangat penting dalam pembentukan karakter siswa.

Pendidikan Agama Islam di sekolah Muhammadiyah disebut dengan istilah ISMUBA (al-Islam, Kemuhammadiyahan dan Bahasa Arab). Ismuba merupakan disiplin ilmu yang menjadikan ciri khusus dan keunggulan sekolah Muhammadiyah (A. N. Huda, 2018).

Tujuan dari pengembangan kurikulum ismuba adalah menjadi standar mutu pengelolaan pendidikan pada sekolah Muhammadiyah, menjadi acuan operasional bagi kepala sekolah dan guru dalam menyusun dan mengelola kurikulum pada tingkat satuan pendidikan secara optimal, dan menjadi acuan operasional bagi Majelis Pendidikan Dasar dan Menengah dalam melakukan koordinasi dan supervisi penyusunan dan pengelolaan kurikulum di setiap satuan pendidikan (Muhammadiyah, 2007)

Adapun muatan atau struktur kurikulum ismuba pada Sekolah Menengah Pertama Muhammadiyah adalah sebagai berikut (Muhammadiyah, 2007).

Tabel 1.1.

Struktur Kurikulum Ismuba

\begin{tabular}{|c|c|c|c|c|c|c|c|}
\hline \multirow{3}{*}{$\begin{array}{l}\mathbf{N} \\
\mathbf{0}\end{array}$} & \multirow{3}{*}{ Mata Pelajaran } & \multicolumn{6}{|c|}{ Kelas, Semester dan Alokasi Waktu } \\
\hline & & \multicolumn{2}{|c|}{ VII } & \multicolumn{2}{|c|}{ VIII } & \multicolumn{2}{|c|}{ IX } \\
\hline & & $\mathbf{1}$ & 2 & 1 & 2 & 1 & 2 \\
\hline 1 & Al-Qu'an (Tahsin, Tilawah, Tahfidz) & 3 & 3 & 3 & 3 & 3 & 3 \\
\hline 2 & Pendidikan Aqidah Akhlak & 2 & 2 & 2 & 2 & 2 & 2 \\
\hline 3 & Pendidikan Fikih & 3 & 3 & 3 & 3 & 3 & 3 \\
\hline 4 & Pendidikan Tarikh & 1 & 1 & 1 & 1 & 1 & 1 \\
\hline 5 & Pendidikan Kemuhammadiyahan & 1 & 1 & 1 & 1 & 1 & 1 \\
\hline 6 & Pendidikan Bahasa Arab & 2 & 2 & 2 & 2 & 2 & 2 \\
\hline & Jumlah Jam & 12 & 12 & 12 & 12 & 12 & 12 \\
\hline
\end{tabular}

Pengembangan kurikulum di SMP Muhammadiyah Banguntapan mengacu pada kurikulum standar nasional yaitu Permendiknas No 22, 23, dan 24 tahun 2006 yang mengamanatkan sekolah untuk menyusun dan melaksanakan Kurikulum Tingkat Satuan Pendidikan (KTSP) dan Permendiknas No 20, 21, 22, 23, 24 tahun 2016 dan kurikulum 
ismuba. Kurikulum standar nasional terdiri atas standar isi, standar proses, standar kompetensi lulusan, tenaga kependidikan, sarana dan prasarana, standar pengelolaan, standar penilaian, serta standar pembiayaan. Sedangkan kurikulum ismuba digunakan khusus untuk mata pelajaran pendidikan agama islam di sekolah Muhammadiyah. Tujuan digunakannya kurikulum di SMP Muhammadiyah Banguntapan adalah untuk djadikan sebagai pedoman penyelenggaraan pembelajaran untuk mencapai tujuan pendidikan di tingkat satuan pendidikan yang berkarakter.

SMP Muhammadiyah Banguntapan berdiri pada tahun 1977 di Dusun Kalangan Baturetno Banguntapan Bantul Yogyakarta dengan nama SMP Muhammadiyah Wiyoro. Pada tahun 1983 gedung SMP Muhammadiyah Banguntapan pindah di lapangan Wiyoro dengan luas lahan $\pm 1000 \mathrm{~m}^{2}$. Sekitar tahun 2010 SMP Muhammadiyah bisa membeli lahan sawah milik masyarakat yang terletak di sebelah selatan gedung utama SMP Muhammadiyah dengan luas lahan sekitar $\pm 300 \mathrm{~m}^{2}$. Selanjutnya pada akhir tahun pelajaran 2017 - 2018, tepatnya pada bulan mei 2017, SMP Muhammadiyah mendapatkan wakaf tanah sawah dari Bapak Drs. Dharsono, M.Pd di sebelah selatan gedung kedua SMP Muhammadiyah Banguntapan sekitar \pm 144 $\mathrm{m}^{2}$, yang sekarang dijadikan sebagai tempat parkir sepeda siswa.

Terkait dengan tenaga pendidik dan tenaga kependidikan, di SMP Muhammadiyah tergolong memiliki tenaga yang cukup mepet jika dilihat dari jumlah rombongan belajarnya. SMP Muhammadiyah memiliki rombongan belajar sejumlah 12 rombel yang terdiri dari 4 rombel kelas 7, 4 rombel kelas 8 , serta 4 rombel kelas 9 . Rata-rata setiap rombel berisi 25-30 siswa dengan jumlah tenaga pendidik dan kependidikan 40 0rang. Berikut rincian tenaga pendidik dan tenaga kependidikan SMP Muhammadiyah Banguntapan: 
a. Tenaga Pendidik

\begin{tabular}{|c|l|c|c|c|c|c|c|c|}
\hline \multirow{2}{*}{ No } & \multirow{2}{*}{ Personil } & \multicolumn{6}{|c|}{ Pendidikan terakhir } & \multirow{2}{*}{ JUMLA } \\
\cline { 3 - 7 } & & S2 & S1 & D3 & D2 & D1 & SMA & H \\
\hline 1 & ASN & - & 6 & - & - & 1 & - & 7 \\
\hline 2 & GTY & - & 9 & 1 & - & - & - & 10 \\
\hline 3 & GTT & - & 11 & - & - & - & - & 11 \\
\hline 4 & Guru Ekstra & 2 & 3 & - & - & - & - & 5 \\
\hline 5 & Guru Tambah Jam & - & 1 & - & - & - & - & 1 \\
\hline \multicolumn{2}{|c|}{ Jumlah } & 2 & 30 & 1 & - & - & - & 33 \\
\hline
\end{tabular}

Tabel 1.2.

Tenaga Pendidik

b. Tenaga Kependidikan

Tabel 1.3.

Tenaga Kependidik

\begin{tabular}{|c|l|c|c|c|c|c|c|c|}
\hline \multirow{2}{*}{ No } & \multirow{2}{*}{ Personil } & \multicolumn{6}{|c|}{ Pendidikan terakhir } & \multirow{2}{*}{ JUMLAH } \\
\cline { 3 - 8 } & & S1 & D3 & D2 & D1 & SMA & SMP & \\
\hline 1 & PTY & - & 1 & - & - & 2 & 1 & 4 \\
\hline 2 & PTT & - & 1 & - & - & - & - & 1 \\
\hline 3 & Jaga Malam & - & - & - & - & - & 1 & 1 \\
\hline 4 & Satpam & - & - & - & - & 1 & - & 1 \\
\hline \multicolumn{2}{|c|}{ Jumlah } & - & 2 & - & - & 3 & 2 & 7 \\
\hline
\end{tabular}

Secara geografis SMP Muhammadiyah Banguntapan terletak di pinggiran kota, tepatnya di jalan Wonosari km 7. Di mana arus globalisasi sangat cepat merambah ke SMP Muhammadiyah Banguntapan, dan secara otomatis berpengaruh pada karakter peserta didik. Degradasi moral yang terjadi pada peserta didik SMP Muhammadiyah Banguntapan, seperti misalnya meninggalkan sholat wajib, suka berbicara kotor, pergaulan bebas, siswa putri yang tidak menutupi auratnya, sering terlambat, berani dengan bapak ibu guru karyawan, dan lain sebagainya dipicu oleh kurangnya penerapan pendidikan karakter terutama di rumah.

Hasil wawancara dengan kepala sekolah SMP Muhammadiyah Banguntapan, yaitu Bapak Riyanto, S.Pd.I, M.S.I bahwa kurikulum ismuba yang diterapkan di SMP Muhammadiyah Banguntapan sudah menerapkan pendidikan karakter dalam setiap mata pelajaran dan pembiasaan lainnya di sekolah. Adapun penerapan kurikulum ismuba dalam pembiasaan sekolah di antaranya adalah sebagai berikut: 
Tabel 1.4.

Penerapan Kurikulum Ismuba

\begin{tabular}{|c|l|l|}
\hline No & \multicolumn{1}{|c|}{ Nama Program } & \multicolumn{1}{|c|}{ Karakter yang dicapai } \\
\hline 1 & $\begin{array}{l}\text { Pelaksanaan Sholat Dhuha dan tadarus di awal } \\
\text { pelajaran }\end{array}$ & $\begin{array}{l}\text { Religius dan } \\
\text { membaca }\end{array}$ \\
\hline 2 & Pembuatan buku monitoring sholat & Disiplin \\
\hline 3 & Pendampingan membaca alquran & Gemar membaca \\
\hline 4 & $\begin{array}{l}\text { Pelaksanaan pengajian rutin wali siswa setiap } \\
\text { Ahad Pon }\end{array}$ & Komunikatif \\
\hline 5 & Pelaksanaan infaq setiap hari Jum'at & Dermawan \\
\hline 6 & Pengadaan bakti sosial & Peduli lingkungan \\
\hline 7 & Pengadaan kantin kejujuran & Jujur \\
\hline
\end{tabular}

Pembiasaan di atas sudah rutin dilaksanakan dengan baik, dan sangat berpengaruh pada karakter peserta didik SMP Muhammadiyah Banguntapan. Wajar apabila masih ada satu dua atau tiga siswa yang masih belum disiplin dalam melaksanakan pembiasaan di sekolah ini. Sebagaimana dijelaskan sebelumnya bahwa kurikulum SMP Muhammadiyah Banguntapan mengacu pada kurikulum standar nasional dan kurikulum ismuba, maka berikut muatan kurikulum SMP Muhammadiyah Banguntapan secara rinci:

Tabel 1.5.

Muatan Kurikulum SMP

\begin{tabular}{|c|c|c|c|c|}
\hline \multirow{2}{*}{\multicolumn{2}{|c|}{ Mata Pelajaran }} & \multicolumn{3}{|c|}{ Alokasi Waktu per Minggu } \\
\hline & & VII & VIII & IX \\
\hline \multicolumn{5}{|c|}{ Kelompok A } \\
\hline 1 & Pendidikan Agama & 9 & 9 & 9 \\
\hline 2 & Pendidikan Pancasila dan Kewarganegaraan & 3 & 3 & 3 \\
\hline 3 & Bbahasa Indonesia & 6 & 6 & 6 \\
\hline 4 & Matematika & 5 & 5 & 5 \\
\hline 5 & Ilmu Pengetahuan Alam & 5 & 5 & 5 \\
\hline 6 & Ilmu Pengetahuan Sosial & 4 & 4 & 4 \\
\hline 7 & Bahasa Inggris & 4 & 4 & 4 \\
\hline \multicolumn{5}{|c|}{ Kelompok B } \\
\hline 1 & Seni Budaya & 3 & 3 & 3 \\
\hline 2 & Pendidikan Jasmani,Olah Raga dan Kesehatan & 3 & 3 & 3 \\
\hline 3 & Prakarya & 2 & 2 & 2 \\
\hline 4 & Bahasa Jawa & 2 & 2 & 2 \\
\hline \multicolumn{5}{|c|}{ Kelompok C } \\
\hline 1 & Bahasa Arab & 2 & 2 & 1 \\
\hline 2 & Kemuhammadiyahan & 1 & 1 & 1 \\
\hline 3 & $\mathrm{BP} / \mathrm{BK}$ & 1 & 1 & 1 \\
\hline & Jumlah Alokasi Waktu per Minggu & 50 & 50 & 50 \\
\hline
\end{tabular}




\begin{tabular}{|c|c|c|c|c|}
\hline \multirow{2}{*}{\multicolumn{2}{|c|}{ Mata Pelajaran }} & \multicolumn{3}{|c|}{ Alokasi Waktu per Minggu } \\
\hline & & VII & VIII & IX \\
\hline \multicolumn{2}{|c|}{ Ekstra Kurikuler } & & & \\
\hline 1 & Hizbul Wathan & & & \\
\hline 2 & Tapak Suci & & & \\
\hline 3 & Marching Band & & & \\
\hline 4 & Kerawitan & & & \\
\hline 5 & Pendidikan Baca Qur'an & & & \\
\hline 6 & Seni baca Al-Qur'an & & & \\
\hline 7 & Sepak bola & & & \\
\hline 8 & Tahfidz Qur'an & & & \\
\hline 9 & Futsal & & & \\
\hline 10 & Paduan Suara & & & \\
\hline 11 & Tari & & & \\
\hline
\end{tabular}

\section{SIMPULAN DAN SARAN}

Berdasarkan hasil penelitian dapat dsimpulkan bahwa penerapan kurikulum ismuba dalam pembentukan karakter islami pada siiswa SMP Muhammadiyah Banguntapan diterapkan dalam pembiasaan-pembaiasaan sekolah di antaranya adalah pembiasaan sholat dhuha dan dhuhur berjamaah, pertemuan rutin wali siswa, pengadaan kantin kejujuran, pengadaan infaq rutin hari Jum'at, serta pendampingan membaca alquran. Karakter islami yang dimaksud di antaranya adalah karakter jujur, dermawan, peduli sosial, religius, komunkatif, gemar membaca serta peduli lingkungan. Di mana telah tercantum dalam kurikulum sekolah yang dipadukan antara kurikulum standar nasional dengan kurikulum ismuba.

Adapun saran yang bisa peneliti sampaikan adalah penerapan kurikulum ismuba ini tetap dilaksanakan secara konsisten dan kompak antara semua elemen pendidikan yaitu, orang tua atau wali siswa (keluarga), sekolah serta masyarakat sekitar, sehingga nantinya SMP Muhammadiyah Banguntapan akan menjadi sekolah rujukan masyarakat dan menjadi sekolah yang unggul. 


\section{DAFTAR PUSTAKA}

Akhwan, M. (2014). Pendidikan Karakter: Konsep dan Implementasinya dalam Pembelajaran di Sekolah/Madrasah. El-Tarbawi, 7(1), 61-67.

Andriani, S., Suyitno, H., \& Junaidi, I. (2019). The Application of Differential Equation of Verhulst Population Model on Estimation of Bandar Lampung Population. Journal of Physics: Conference Series, 1155, 012017.

Anggoro, B. S., Efendi, H., \& Suherman, S. (2019). The Impact Of EthnomathematicsBased Probing-Prompting Learning Method On Class IX SMP Negeri 2 Way Tenong Students'mathematical Communication Skills Year 2016/2017. Asian Journal of Current Research, 1-8.

Damayanti, E., Septuri, S., \& Suherman, S. (2019). Pengetahuan Deklaratif Siswa Tunanetra Dalam Pembelajaran Matematika. Inovasi Pembangunan: Jurnal Kelitbangan, 7(2), 173-173.

Efendi, M. (2017). PENERAPAN PENDIDIKAN KARAKTER MELALUI PROGRAM GERAKAN KEPANDUAN HIZBUL WATHAN PADA SEKOLAH DASAR MUHAMMADIYAH VI PALEMBANG. Conciencia, 17(1), 27-39.

Fahrudin, F. (2017). Implementasi Kurikulum 2013 Pendidikan Agama Islam dan Budi Pekerti Dalam Menanamkan Akhlakul Karimah Siswa. EDU-RILIGIA: Jurnal Ilmu Pendidikan Islam Dan Keagamaan, 1(4).

Farida, F., Suherman, S., \& Zulfikar, S. (2019). Peningkatan Kemampuan Pemahaman Konsep Himpunan Melalui Pembelajaran Matematika dengan Media Articulate Studio'13. JSHP: Jurnal Sosial Humaniora Dan Pendidikan, 3(1), 20-28.

Gumanti, A. A. M., Supriadi, N., \& Suherman, S. (2018). Pengaruh Pembelajaran dengan Musik Klasik Terhadap Kemampuan Pemecahan Masalah Matematis Peserta Didik. Prosiding Seminar Nasional Matematika Dan Pendidikan Matematika, 1, 393-399.

Hamidah, K., \& Suherman, S. (2016). Proses Berpikir Matematis Siswa dalam Menyelesaikan Masalah Matematika di tinjau dari Tipe Kepribadian Keirsey. AlJabar: Jurnal Pendidikan Matematika, 7(2), 231-248.

Hartinah, S., Suherman, S., Syazali, M., Efendi, H., Junaidi, R., Jermsittiparsert, K., \& Umam, R. (2019). Probing-Prompting Based On Ethnomathematics Learning Model: The Effect On Mathematical Communication Skill. Journal for the Education of Gifted Young Scientists, 7(4), 799-814.

Huda, A. N. (2018). Evaluasi Kurikulum Al Islam Kemuhammadiyahan dan Bahasa Arab Berbasis Integratif-Holistic di SMA Muhammadiyah 1 Muntilan. Tarbiyatuna, 9(2). 
Huda, S., Rinaldi, A., Suherman, S., Sugiharta, I., Astuti, D. W., Fatimah, O., \& Prasetiyo, A. E. (2019). Understanding of Mathematical Concepts in the Linear Equation with Two Variables: Impact of E-Learning and Blended Learning Using Google Classroom. Al-Jabar: Jurnal Pendidikan Matematika, 10(2), 261270.

Islam, S. (2017). Karakteristik pendidikan karakter; menjawab tantangan multidimensional melalui implementasi Kurikulum 2013. Jurnal Edureligia, 1(2), 89-100.

Judiani, S. (2010). Implementasi pendidikan karakter di sekolah dasar melalui penguatan pelaksanaan kurikulum. Jurnal Pendidikan Dan Kebudayaan, 16(9), 280-289.

Kamandoko, K., \& Suherman, S. (2017). Profil Intuisi Matematis Siswa dalam Pemecahan Masalah Matematika Ditinjau dari Gaya Kognitif Field Independent dan Field Dependent. Jurnal Penelitian LPPM (Lembaga Penelitian Dan Pengabdian Kepada Masyarakat) IKIP PGRI MADIUN, 5(1), 1-8.

Komarudin, K. (2017). Analisis kesalahan siswa dalam pemecahan masalah matematika pada materi peluang berdasarkan high order thinking dan pemberian scaffolding. Jurnal Darussalam: Jurnal Pendidikan, Komunikasi Dan Pemikiran Hukum Islam, 8(1), 202-217.

Lestari, I. (2018). Pengembangan Bahan Ajar Matematika dengan Memanfaatkan Geogebra untuk Meningkatkan Pemahaman Konsep. GAUSS: Jurnal Pendidikan Matematika, 1(1), 26-36.

Machali, I. (2014). Kebijakan perubahan kurikulum 2013 dalam menyongsong Indonesia emas tahun 2045. Jurnal Pendidikan Islam, 3(1), 71-94.

Muhammadiyah, M. D. P. (2007). Standar Isi dan Kompentensi Lulusan Pendidikan AlIslam dan Kemuhammadiyahan. Jakarta: Majelis Dikdasmen PP. Muhammadiyah.

Nuriyanto, L. K. (2014). Model Kurikulum Pendidikan Agama Islam di SDIT al-Anwar dan Firdaus Mojokerto Jawa Timur. EDUKASI: Jurnal Penelitian Pendidikan Agama Dan Keagamaan, 12(1).

Ramdhani, M. A. (2017). Lingkungan Pendidikan dalam Implementasi Pendidikan Karakter. Jurnal Pendidikan UNIGA, 8(1), 28-37.

Rizqi, A., Parmin, P., \& Nurhayati, S. (2013). Pengembangan Modul IPA Terpadu Berkarakter Tema Pemanasan Global untuk Siswa SMP/MTs. Unnes Science Education Journal, 2(1). 
Rodiawati, H., \& Komarudin, K. (2018). Pengembangan e-learning melalui modul interaktif berbasis learning content development system. Jurnal Tatsqif, 16(2), $172-185$.

Rumapea, M. E. (2014). Kurikulum 2013 yang Berkarakter. JUPIIS: JURNAL PENDIDIKAN ILMU-ILMU SOSIAL, 5(2).

Sugiono. (2007). Kualitatif dan R\&D. Bandung: Alfabeta.

Suryawati, D. P. (2016). Implementasi Pembelajaran Akidah Akhlak Terhadap Pembentukan Karakter Siswa di MTs Negeri Semanu Gunungkidul. Jurnal Pendidikan Madrasah, 1(2), 309-322.

Tantowi, T. R., \& Widodo, H. (2019). IMPLEMENTASI PENDIDIKAN KARAKTER PADA KURIKULUM ISMUBA SD MUHAMMADIYAH KALISOKA SENTOLO KULONPROGO DIY. Muaddib: Studi Kependidikan Dan Keislaman, 1(1), 54-63.

Utami, R. D. (2016). Membangun Karakter Siswa Pendidikan Dasar Muhammadiyah Melalui Identifikasi Implementasi Pendidikan Karakter Di Sekolah. Profesi Pendidikan Dasar, 2(1), 32-40.

Utami, T. N., Jatmiko, A., \& Suherman, S. (2018). Pengembangan Modul Matematika dengan Pendekatan Science, Technology, Engineering, And Mathematics (STEM) pada Materi Segiempat. Desimal: Jurnal Matematika, 1(2), 165-172.

Wardoyo, S. M. (2015). Pendidikan Karakter: Membangun Jatidiri Bangsa Menuju Generasi Emas 2045 Yang Religius. TADRIS: Jurnal Pendidikan Islam, 10(1), 90-103.

Widayanti, F. E. (2019). IMPLEMENTASI KURIKULUM ISMUBA DI MI UNGGULAN MUHAMMADIYAH LEMAHDADI. Al-Tadzkiyyah: Jurnal Pendidikan Islam, 10(1), 69-79.

Yanti, A. P., \& Syazali, M. (2016). Analisis proses berpikir siswa dalam memecahkan masalah matematika berdasarkan langkah-langkah Bransford dan Stein ditinjau dari Adversity Quotient. Al-Jabar: Jurnal Pendidikan Matematika, 7(1), 63-74.

Yunianto, T., Negara, H. S., \& SUuherman, S. (2019). FLIP BUILDER: PENGEMBANGANNYA PADA MEDIA PEMBELAJARAN MATEMATIKA. TERAMPIL: Jurnal Pendidikan Dan Pembelajaran Dasar, 6(2), 115-127. 